\title{
Üniversite Öğrencilerinin Duygusal Öz-Yeterlik ile Sıkıntıya Dayanma Düzeyi İlişsisi
}

\section{Relationship between Emotional Self-Efficacy and Distress Tolerance of University Students}

\author{
Zeynep Akkuş Çutuk ${ }^{\mathrm{a} *}$

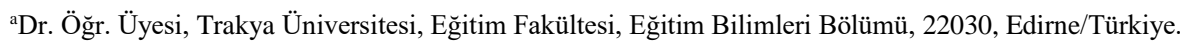 \\ ORCID: 0000-0001-8364-4431
}

\section{MAKALE BİLGİṠ \\ Makale Geçmişi: \\ Başvuru tarihi: 23 Ağustos 2018 \\ Düzeltme tarihi: 03 Kasım 2018 \\ Kabul tarihi: 17 Aralık 2018}

\section{Anahtar Kelimeler:}

Duygusal Öz-Yeterlik

Sıkıntıya Dayanma

Üniversite Öğrencileri
ÖZ

$\mathrm{Bu}$ araştırmada, üniversite öğrencilerinin duygusal öz-yeterlik ile cinsiyet, kardeş sayısı, anne baba tutumu, sosyo-ekonomik düzey ve sıkıntıya dayanma düzeyi arasındaki ilișki incelenmiștir. Araştırmada ilişkisel tarama modeli kullanılmıştır. Araştırmanın örneklemini, 287'si kadın, 103'ü erkek olmak üzere toplam 390 üniversite öğrencisi oluşturmaktadır. Araştırmada veri toplama arac1 olarak Kișisel Bilgi Formu, Duygusal Öz-Yeterlik Ölçeği ve Sıkıntıya Dayanma Ölçeği uygulanmıştır. Araştırmada T-testi, tek yönlü Varyans Analizi (One Way Anova), Pearson Momentler Çarpım Korelasyon Katsayısı ve Basit Doğrusal Regresyon Analizi teknikleri kullanılmıştır. Araştırmanın sonucunda, cinsiyetin, kardeş sayısının, anne baba tutumunun ve sosyoekonomik durumun duygusal öz-yeterlik düzeyi üzerinde etkisinin olmadığı, duygusal öz-yeterlik ile sıkıntıya dayanma düzeyi arasında anlamlı ve pozitif yönde bir ilişki olduğu ve sıkıntıya dayanmanın duygusal öz-yeterlik düzeyini anlamlı bir şekilde yordadığı bulunmuştur.

\section{A B S T R A C T}

In this research, the relationship between university students' emotional self-efficacy and age, the number of sibling, parental attitude, socio-economic level and distress tolerance were investigated. Relational model was used in the research. The research sample consists of 390 students, 287 of whom are female and 103 of whom are male. In this research, Personal Information Form, Emotional Self-Efficacy Scale and Distress Tolerance Scale were used as data collection tools. The data were analyzed with T-Test, One Way Anova Analysis, Pearson Momentler Crossing Correlation Technique and Simple Linear Regression techniques. As a result of this research, there was no significant effect of gender, number of siblings, parental attitude and socio-economic status on emotional self-efficacy, and that there was a significant and positive relationship between emotional self-efficacy and the level of distress tolerance. The level of distress tolerance significantly predicted emotional self-efficacy level.

\section{Giriş}

Öz-yeterlik, insanların yaşamlarını etkileyen olaylar üzerinde etkili olan performans düzeylerini ortaya koyma yeteneklerine ilişkin inançları olarak tanımlanmaktadır (Bandura, 1994). Öz-yeterlik, bir kişinin hareket tarzını belirleyebilir ve zorlu durumların üstesinden gelmek için göstereceği çabayı ve kararlılık düzeyini etkileyebilir (Bandura,1982).

Petrides ve Furnham (2001, 2003) duygusal zekanın iki temel yönü olduğunu belirtmiştir: kişisel özellik olarak duygusal zeka (duygusal öz-yeterlik) ve yetenek olarak

* Sorumlu yazar/Corresponding author.

e-posta: zeynepacutuk@trakya.edu.tr duygusal zeka (bilişsel-duygusal yetenek). Petrides ve Furnham (2003) duygusal öz-yeterliliğin, davranışsal eğilimleri ve duygusal işlevsellikle ilgili kişinin kendisine ilişkin algılarını içerdiğini belirtmiştir. Kirk, Shutte, \& Hine (2011) duygusal işlevsellikle ilgili benlik algılarının, duygusal öz-yeterliliği içerdiğini, fakat duygusal işlevselliğin aynı zamanda benlik algısının ve diğer eğilimlerin başka yönlerini de içerdiğini ifade etmiştir. Bundan dolayı, duygusal öz-yeterliliğin, duygusal zekanın bir özelliği veya niteliği olduğunu ve duygusal öz-yeterlik ile aynı kabul edilemeyeceğini belirtmiştir. Öz-yeterlik, belli bir alana özgü işlevselliğin önemli bir yordayıcısı olduğu için, duygusal işlevsellik de öz-yeterlilik, gerçek duygusal 
süreçleri ve uyumlu ve uyumsuz duygusal işlevsellikle ilgili sonuçları etkileyebilir (Kirk, Schutte ve Hine, 2008). Muris (2002) duygusal öz-yeterliği, bir kişinin olumsuz duygularla başa çıkabilme yeteneği olarak tanımlar. Duygusal özyeterlik inançları, bireylerin olumsuz duygusal durumları önleme (örn., sinirliliğin önlenmesi, olumsuz düşüncelerin bastırılması) veya olumsuz duygusal bir durumu yaşarken normal duygusal duruma geri dönme yeteneği olarak ișlevselleştirilir (örn., olumlu bir tutum elde etmek için kendi kendine telkinde bulunma, korktuğunda ya da kaygılı hissettiğinde kendini sakinleştirme) (Bandura, 1997; Muris, 2002).

Sıkıntıya dayanma, olumsuz psikolojik durumları yaşama ve bunlara katlanma kapasitesi olarak tanımlanmıştır (Simons ve Gaher, 2005). Benzer şekilde; Leyro vd., (2010); Brown ve diğerlerine, (2005) göre sıkıntıya dayanma, olumsuz psikolojik ve fiziksel durumlara ya da bu durumlar sonucu oluşan olumsuz duygulanıma katlanma kabiliyeti olarak tanımlanır. Simons ve Gaher'e (2005) göre sıkıntı, bilişsel veya fiziksel süreçlerin sonucu olabilir, ancak, genellikle duygusal deneyimleri hafifletmeye yönelik davranış eğilimleri ile nitelendirilen duygusal durumlarda ortaya çıkar. Sıkıntıya dayanma, olumsuz duygusal durumlar karşısında; dayanma gücü ve caydırıcılık, değerlendirme ve kabul edilebilirlik, dikkati dağıtma ve işleyişini bozma eğilimi ve duyguların düzenlenmesi gibi eylemler sonucu, olumsuz duygusal durumlarin önlenmesine ya da zayıflatılmasına yönelik değerlendirme ve beklentilerden oluşur (Simons ve Gaher, 2005). Bu anlamda sıkıntıya dayanma, duygusal öz-yeterlik gibi olumsuz duygularla başa çıkabilmeyi sağlamaktadır.

Nelson (1990) yaşamda karşılaşılan zorlukların duygusal iyi oluşun önemli bir yordayıcısı olduğunu, bu zorluklarla başa çıkmanın bunların yarattığı olumsuz etkileri azalttığını ve olumlu duygu durumu ile ilişkili olduğunu ifade etmiştir. Duygusal sıkıntıyı olumsuz olarak değerlendiren ve tolere edemeyen bireylerin, aşırı ve kontrol edilemeyen bir endişe eğilimi geliştirme olasılığı daha yüksektir (Huang, Szabó \& Han, 2009). Anestis vd. (2007) tarafından yapılan çalışmada düşük sıkıntıya dayanma düzeyi ile aşırı yeme, depresyon, kaygı, dürtüsellik gibi birçok davranışın ilişsili olduğu bulunmuştur. Akça (2016) sıkıntıya dayanma düzeyi arttıkça depresyon, anksiyete ve stres düzeyinin azaldığını belirlemiștir. Kraemer vd. (2013) düşük sıkıntıya dayanma düzeyinin sigarayı bırakmada bir engel olduğunu, Brockman, (2009) bu kişilerin, olumsuz duygularını azaltmak için alkol tüketme eğiliminde olduğunu ifade etmiştir.

Duygusal öz-yeterlik, kişinin kendi duygusal tepkilerini ve diğerlerinin duygusal tepkilerini değerlendirme becerisi ile ilişkilendirilir. Yüksek düzeyde duygusal öz-yeterliliğe sahip insanlar, genellikle kendilerinin ve başkalarının duygularının büyük ölçüde farkındadır ve onlara karşı duyarlıdırlar. Olumsuz duygusal deneyimlere açıktır ve bu deneyimleri kabul ederler ve duygularını değiştirebilirler (Saarni, 1999). Ayrıca yüksek düzeyde duygusal özyeterliğin bireyin ruh sağlığını koruyucu bir etken olduğu belirtilmektedir (Sahranç, 2007). Duygusal öz-yeterlik, bireyin öz-güveni, zorlu hedeflere ulaşma kabiliyeti ve bu hedeflere ulaşma yolunda göstereceği sabır için oldukça önemlidir (Saarni, 1999). Öz-yeterlik inançları, insanların nasıl hissettiğini, düşündüğünü, kendilerini nasıl motive ettiğini ve nasıl davrandığını belirler. Bu inançlar, bilișsel, motivasyonal, duygusal ve seçim süreçlerini içerir (Bandura, 1994). Güçlü bir öz-yeterlik duygusu, birçok yönden başarıyı ve kişisel iyi oluşu, artırır. Böylesi etkili bir bakış açısı, kișisel başarıları artırır, stresi ve depresyona karşı yatkınlığı azaltır. Bunun tam tersi, yeteneklerinden şüphe duyan insanlar, kişisel tehdit olarak gördükleri zorlu görevlerden uzaklaşırlar. Onların istekleri az ve hedeflerine olan inançları zayıftır. Bunun sonucu olarak stres ve depresyona daha yatkındırlar (Bandura vd., 1999).

Bandura'ya (1997) göre, öz-yeterlik, duygusal bozuklukların ortaya çıkmasında ve sürmesinde önemli bir rol oynar. Bandura vd., (1999), yaptıkları çalışmada, düşük öz-yeterlik düzeyinin uzun süreli depresyonun yordayıcısı olduğunu bulmuştur. Duygusal öz-yeterlik, hem kayg1 hem de depresyon belirtileri ile güçlü ve olumsuz bir şekilde ilişkilidir (Muris, 2002; Tahmassian ve Moghadam, 2011). Başka bir çalışmada, duygusal öz-yeterliliğin, ergenlerde dikkat kontrolü ile duygusal ve davranışsal sorunlar arasındaki ilişkilere aracılık ettiği gösterilmiştir (Muris vd., 2008). Caprara vd., (2008) duygusal öz-yeterlik ile saldırgan davranışlar arasında negatif bir ilişki olduğunu ortaya koymuştur.

Duygusal öz-yeterlik düzeyi cinsiyete göre incelendiğinde; ilgili alan yazında cinsiyetin duygusal öz-yeterlik üzerinde bir etkisinin olmadığını belirten çalışmalar (Colomeischi ve Colomeischi, 2014) ile birlikte duygusal öz-yeterliliğin cinsiyete göre anlamlı düzeyde farklılık gösterdiğini belirten çalışmalar (Telef ve Karaca, 2011) olduğu dikkati çekmektedir ve bu araştırma kapsamında incelenmesine ihtiyaç duyulmuştur.

Telef (2011) ve Ceylan (2013) tarafindan ergenler üzerinde yapılan çalışmalarda, kardeş sayısının duygusal öz-yeterlik üzerinde etkili olmadığı saptanmıştır. Ancak bu çalışma üniversite öğrencileri üzerinde yapıldığından kardeş sayısının etkisi incelemeye alınmıştır.

Anne baba tutumu açısından bakıldığında, ilgisiz anne baba tutumunda, çocuk fiziksel ve duygusal olarak yalnız kalmaktadır. $\mathrm{Bu}$ tutumla yetişen çocuklarda özgüven eksikliği, duygu ve düşüncelerini ifade edememe gibi sosyal, duygusal, bilişsel ve birçok alanda gerilik görülebileceği ifade edilmektedir (Sakarya, 2013). Buna karşın anne baba tutumunun, duygusal öz-yeterlik üzerinde etkili olmadığı belirtilmektedir (Ceylan, 2013).

Ailenin gelir düzeyi yükseldikçe, öz-yeterlik inancının arttığ1, ekonomik durumun bireyin kendine olan güven duygusunu etkilediği savunulmaktadır (Mengi, 2011). Aksine sosyo-ekonomik düzeyin duygusal öz-yeterlik üzerinde etkisinin olmadığı ifade edilmektedir (Demirdüzen, 2013).

Yukarıda dile getirilen teorik alt yapı 1şığında, duygusal özyeterlik ile sıkıntıya dayanmanın ilişkili olabileceği düşünülmektedir. Literatürde bu ilişkiye dönük çalışmaların yapılmadığı görülmüştür. Bu araştırma ile hem duygusal özyeterlik ve sıkıntıya dayanma düzeyleri arasındaki ilişkiyi belirlemek hem de duygusal öz-yeterliği çeşitli değişkenlere göre inceleyerek alan yazına katkı sağlanması hedeflenmektedir. Bu amaç doğrultusunda araştırmada şu sorulara yanıt aranmıştır; 
(i) Üniversite öğrencilerinin cinsiyetlerine göre duygusal öz-yeterlik düzeyleri arasında anlamlı bir farklılık var midır?

(ii) Üniversite öğrencilerinin kardeş sayısına göre duygusal öz-yeterlik düzeyleri arasında anlamlı bir ilişki var mıdır?

(iii) Üniversite öğrencilerinin algılanan anne baba tutumuna göre duygusal öz-yeterlik düzeyleri arasında anlamlı bir farklılık var midır?

(iv) Üniversite öğrencilerinin algılanan sosyoekonomik düzeye göre duygusal öz-yeterlik düzeyleri arasında anlamlı bir farklılık var mıdır?

(v) Üniversite öğrencilerinin duygusal öz-yeterlik ile sıkıntıya dayanma düzeyleri arasında anlamlı bir ilişki var mıdır?

(vi) Üniversite öğrencilerinin sıkıntıya dayanma düzeyi duygusal öz-yeterlik düzeylerini anlamlı bir şekilde yordamakta midır?

\section{Yöntem}

$\mathrm{Bu}$ bölümde, araştırmanın modeli, çalışma grubu, veri toplama aracı, verilerin toplanması ve analizi ile ilgili bilgiler yer almaktadir.

\subsection{Araștırma Modeli}

Araştırmada ilişkisel tarama modeli kullanılmıştır. İlişkisel tarama modelleri, iki ve daha çok sayıdaki değişken arasında birlikte değişim varlığını ve/veya derecesini belirlemeyi amaçlayan araştırma modelleridir. Bu tür bir düzenlemede, aralarında ilişki aranacak değişkenler, tekil taramada olduğu gibi, ayrı ayrı sembolleștirilir. Ancak bu sembolleştirme (değer verme, ölçme), ilişkisel bir çözümlemeye olanak verecek şekilde yapılmak zorundadır (Karasar, 1995: 81). Bu modele uygun olarak bağımlı ve bağımsız değişkenler arasındaki ilişkilerin varlığı ve derecesi ortaya konmaya çalıșılmıştır. Araştırmanın bağımlı (yordanan) değişkeni, duygusal öz-yeterlik düzeyi, bağımsız (yordayıc1) değişkenler ise cinsiyet, kardeş sayısı, algılanan anne baba tutumu, algılanan sosyo-ekonomik düzey ve sıkıntıya dayanma düzeyidir.

\section{2. Çalışma Grubu}

$\mathrm{Bu}$ araştırma, Sakarya Üniversitesi Eğitim Fakültesi Rehberlik ve Psikolojik Danışmanlık, Sınıf Öğretmenliği, İlköğretim Matematik Öğretmenliğii, Türkçe Öğretmenliği, İngilizce öğretmenliği ve Okul Öncesi Öğretmenliği bölümlerinde öğrenim gören ve tesadüfi örnekleme yoluyla seçilen 287'si (\%74) kadın, 103'ü (\%26) erkek olmak üzere toplam 390 öğrenci üzerinde yürütülmüştür. Öğrenciler, 1838 yaşları arasında olup, yaş ortalaması 20.98 (Ss:1.70)'dir. Katılımcıların bölümlere göre dağılımları ele alındığında; Rehberlik ve Psikolojik Danışmanlıktan 91 (\%23.3), Sınıf Öğretmenliğinden 75 (\% 19.2), İlköğretim Matematik Öğretmenliğinden 46 (\%11.7), Türkçe Öğretmenliğinden 82 (\%21), İngilizce öğretmenliğinden 56 (\%14.3), Okul Öncesi Öğretmenliğinden $40 \quad(\% 10.2)$ öğrencinin yer aldığ görülmektedir.

Sınıf düzeylerine göre dağılımları incelendiğinde; katılımciların 112'sinin (\%28.7) birinci sınıfta, 128'inin (\%32.8) ikinci sınıfta, 89’unun (\%22.8) üçüncü sınıfta ve 61'inin (\%15.6) dördüncü sinıfta öğrenimlerine devam ettikleri görülmektedir.

\subsection{Veri Toplama Arac1}

Araştırmada veri toplama aracı olarak Kişisel Bilgi Formu, Duygusal Öz-Yeterlik Ölçeği ve Sıkıntıya Dayanma Ölçeği kullanılmıştır.

\subsubsection{Kişisel Bilgi Formu}

Araştırmacı tarafından, örneklem grubunun demografik (cinsiyet, kardeş sayısı, anne baba tutumu, sosyo-ekonomik düzey) özelliklerini belirlemek için 4 sorudan oluşan "Kişisel Bilgi Formu” hazırlanmıştır.

\subsubsection{Duygusal Öz-Yeterlik Ölçeği}

Ölçeğin başlangıç madde havuzu, Mayer ve Salovey (1997) ile Mayer, Salovey ve Caruso'nun (2004) çalışmalarına dayanarak Kirk, Shutte ve Hine (2008) tarafindan yapılmıştır. Türkçe'ye, Totan, İkiz ve Karaca (2010) tarafından uyarlanmıştır. Geçerlik ve güvenirlik çalışmaları, Dokuz Eylül Üniversitesi Buca Eğitim Fakültesinde eğitim gören 231'i k1z, 180'i erkek olmak üzere toplam 411 üniversite öğrencisi üzerinde gerçekleştirilmiştir. Ölçek için duyguları algılama, duyguları düşünceyi destekleyici olarak kullanma, duyguları anlama ve duyguları düzenleme olarak adlandırılan dört faktörlü bir yapı önerilmiştir. Ölçek, beşli Likert tipinde (1 hiç değil, 5 çok) ve 32 maddeden oluşmaktadır. Ölçeğin, Cronbach alfa iç tutarlık güvenirlik katsayısı .96; iki hafta arayla yapılan test-tekrar test iç güvenirlik katsayısı .85 olarak bulunmuştur. Benzer ve zıt ölçekler üzerinden yapılan geçerlik çalışmasında; ölçeğin benzer bir takım ölçekle pozitif yönde, zıt bir takım ölçekle ise negatif yönde anlamlı ilişkileri olduğu bulunmuştur (Totan, İkiz ve Karaca, 2010).

\subsubsection{Sikıntıya Dayanma Ölçeği}

Sıkıntıya Dayanma Ölçeği, Simons \& Gaher (2005) tarafından geliştirilmiştir. Türkçe'ye uyarlaması Sargın ve ark. (2012) ile Akın, Akça ve Gülşen (2014) tarafından yapılmıştır. Bu araştırmada Akın, Akça ve Gülşen (2014) tarafından uyarlanan ölçek kullanılmıştır. Ölçek, dört alt boyuttan (dayanıklılık, yoğunlaşma, değerlendirme ve düzenleme) ve 15 maddeden oluşmaktadır. Ölçek, 5'li likert tipi (1 tamamen katılıyorum, 5 tamamen katılmıyorum) şeklinde bir derecelendirmeye sahiptir. Ölçeğin yap1 geçerliği için uygulanan doğrulayıcı faktör analizi sonucunda modelin iyi uyum verdiği bulunmuştur $\left(x^{2}=316.43, \quad s d=84, \quad p=0.00, \quad\right.$ RMSEA $=.071, \quad N F I=.94$, $\mathrm{CFI}=.95, \mathrm{IFI}=.95, \mathrm{RFI}=.92, \mathrm{GFI}=.93 \mathrm{SRMR}=.053$ ). Ölçeğin faktör yükleri .27 ile .72 arasında değişmektedir. Ölçeğin, alt boyutlarının iç tutarlılık güvenirlik katsayıları; ölçeğin bütünü için .82, dayanıklılık alt boyutu için .62, yoğunlaşma alt boyutu için .66, değerlendirme alt boyutu için .71 ve düzenleme alt boyutu için .61 olarak bulunmuştur. Testtekrar test iç güvenirlik katsayıları; ölçeğin bütünü için .63, dayanıklılık alt boyutu için .60, yoğunlaşma alt boyutu için .62, değerlendirme alt boyutu için .64 ve düzenleme alt boyutu .58 olarak bulunmuştur. Ölçeğin, düzeltilmiş madde toplam korelasyonları .25 ile .59 arasında siralanmaktadır (Akın, Akça ve Gülşen, 2014). 


\subsection{Verilerin Toplanması ve Analizi}

Araştırmada kullanılan veri toplama araçlarının uygulanması 2015-2016 öğretim ikinci yarıyılında gerçekleştirilmiştir. Uygulama doğrudan araştırmacı tarafından ders saatlerinde gerçekleştirilmiştir. Veri toplama araçlarından elde edilen veriler, SPSS 22.00 for Windows paket programı kullanılarak analiz edilmiştir. Değişkenlerin normal dağılım gösterip göstermedikleri Kolmogorov-Smirnov Testi ile test edilmiş ve test sonuçlarına göre değişkenlerin $(p>0.05)$ normal dağılım gösterdikleri görülmüştür.

Buna göre, üniversite öğrencilerinin cinsiyetlerine göre duygusal öz-yeterlik düzeyleri arasında anlamlı bir fark olup olmadığı t testi ile incelenmiştir. Araştırmada, duygusal özyeterlik ölçeğinden alınan puanlar eşit aralıkta olduğu, dağılım normal, puanlar homojen ve grup sayısı iki olduğu için t-testi kullanılmıştır.

Üniversite öğrencilerinin duygusal öz-yeterlik düzeyleri ile kardeş sayısı, algılanan anne baba tutumu ve algılanan sosyo-ekonomik düzey arasında anlamlı bir fark olup olmadığı Tek Yönlü Varyans Analizi (One Way Anova) ile incelenmiştir. Bağımlı değişkendeki puanlar hem homojen hem de normal dağıldığı ve grup sayıları da ikiden fazla olduğu için Tek Yönlü Varyans Analizi (One Way Anova) tercih edilmiştir.

Öğrencilerin duygusal öz-yeterlik ve sıkıntıya dayanma düzeyi arasındaki ilişkinin yönü ve düzeyini belirlemek amaciyla da Pearson Momentler Çarpım Korelasyon Katsayısı hesaplanmıştır. Duygusal Öz-yeterliliğin sıkıntıya dayanma düzeyini anlamlı düzeyde yordayıp yordamadığ Basit Doğrusal Regresyon Analizi tekniği, Regresyon katsayılarının anlamlılığı için $\mathrm{t}$ testi kullanılmıştır.

\section{Bulgular ve Yorumlar}

$\mathrm{Bu}$ bölümde, duygusal öz-yeterlik düzeyleri ile cinsiyet, kardeş sayısı, algılanan anne baba tutumu, algılanan sosyoekonomik düzey ve sıkıntıya dayanma düzeyi arasındaki ilişkiye yönelik yapılan analizlere yer verilmiştir.

Tablo 1. Araştırmaya Katılan Bireylerin Cinsiyet, Kardeş Sayısı, Algılanan Anne Babanın Tutumu ve Algılanan Sosyo-Ekonomik Düzeye Göre Dağılımı

\begin{tabular}{|c|c|c|c|}
\hline Değişkenler & & $\operatorname{Sayı}(N)$ & Yüzde(\%) \\
\hline \multirow{3}{*}{ Cinsiyet } & Kadın & 287 & $\% 74$ \\
\hline & Erkek & 103 & $\% 26$ \\
\hline & Toplam & 390 & 100 \\
\hline \multirow{6}{*}{ Kardeş Sayıs1 } & Tek Çocuk & 18 & $\% 5$ \\
\hline & İki Kardeş & 132 & $\% 34$ \\
\hline & Üç Kardeş & 133 & $\% 34$ \\
\hline & Dört Kardeş & 60 & $\% 15$ \\
\hline & Beş ve Üstü & 47 & $\% 12$ \\
\hline & Toplam & 390 & 100 \\
\hline \multirow{5}{*}{ Anne Babanın Algılanan Tutumu } & İlgisiz & 7 & $\% 2$ \\
\hline & Otoriter & 40 & $\% 10$ \\
\hline & Koruyucu & 244 & $\% 63$ \\
\hline & Demokratik & 99 & $\% 25$ \\
\hline & Toplam & 390 & 100 \\
\hline \multirow{4}{*}{ Algılanan Sosyo-Ekonomik Düzey } & Düşük & 15 & $\% 4$ \\
\hline & Orta & 357 & $\% 91$ \\
\hline & Yüksek & 18 & $\% 5$ \\
\hline & Toplam & 390 & 100 \\
\hline
\end{tabular}

Tablo 1 incelendiğinde, araştırmaya katılan toplam 390 katılımcının 287'sinin (\%74) kadın, 103'ünün (\%26) erkek olduğu görülmektedir.

Kardeş sayısına göre katılımcıların, 18'inin (\%5) tek çocuk, 132’sinin (\%34) iki kardeş, 133'ünün (\%34) üç kardeş, 60’ının (\%15) dört kardeş ve 47'sinin (\%12) beş kardeş ve üstü olduğu görülmektedir.

Anne babanın tutumuna göre bakıldığında, katılımcıların 7'si (\%2) ilgisiz, 40’1 (\%10) otoriter, 244'ü (\%63) koruyucu ve 99'u (\%25) demokratik olduğunu belirtmiştir.

Araştırmaya katılan tüm bireylerin 15'i (\%4) sosyo-ekonomik düzeylerinin düşük olduğunu, 357'si (\%91) orta olduğunu ve 18'i (\%5) yüksek olduğunu belirtmiştir.

Tablo 2. Cinsiyetlere Göre, Duygusal Öz-Yeterlik Ölçeğinden Alınan Puanların T-Testi Sonuçları

\begin{tabular}{lcccccc}
\hline Cinsiyet & N & X & S & Sd & T & P \\
\hline K1z & 287 & 117.19 & 13.82 & 388 & .082 & .934 \\
\hline Erkek & 103 & 117.05 & 14.87 & & \\
\hline
\end{tabular}

Tablo 2'de görüldüğü üzere, öğrencilerin duygusal öz-yeterlik ölçeğinden aldıkları puanlar, cinsiyetlerine göre anlamlı bir farklılık göstermemektedir $(\mathrm{t}(388)=.082, \mathrm{p}>.05)$. 
Tablo 3. Kardeş Sayısı, Algılanan Anne Baba Tutumu ve Algılanan Sosyo-Ekonomik Düzeye Göre Duygusal Öz-Yeterlik Ölçeğinden Alınan Puan Ortalamaları ve Standart Sapma Değerleri

\begin{tabular}{lccc}
\hline Değişkenler & N & X & S \\
\hline Kardeş Sayıs1 & 390 & 2.95 & 1.04 \\
\hline Algılanan Anne Baba Tutumu & 390 & 3.11 & .65 \\
\hline Algılanan Sosyo-Ekonomik Düzey & 390 & 2.02 & .26 \\
\hline
\end{tabular}

Tablo 3 incelendiğinde, duygusal öz-yeterlik ölçeğinden alınan puanların, kardeş sayısına göre X=2.95, Ss=1.04 olduğu, algilanan anne baba tutumuna göre $\mathrm{X}=3.11, \mathrm{Ss}=.65$ ve algılanan sosyo-ekonomik düzeye göre $\mathrm{X}=2.02$, Ss=.26 olduğu belirlenmiştir.

Tablo 4. Kardeş Sayısına Göre, Duygusal Öz-Yeterlik Ölçeğinden Alınan Puanların ANOVA Sonuçları

\begin{tabular}{lccccc}
\hline Varyansın Kaynă̆ı & Kareler Toplamı & Sd & Kareler Ortalaması & F & P \\
\hline Gruplar arası & 612.531 & 4 & 153.133 & .770 & \\
\hline Gruplar içi & 76608.928 & 385 & 198.984 & \\
\hline Toplam & 77221.459 & 389 & & \\
\hline
\end{tabular}

Tablo 4'de görüldüğü üzere, öğrencilerin duygusal öz-yeterlik ölçeğinden aldıkları puanlar, kardeş sayısına göre anlamlı bir farklılık göstermemektedir $(\mathrm{F}(4-385)=.770, \mathrm{p}>.05)$.

Tablo 5. Algılanan Anne Baba Tutumuna Göre, Duygusal Öz-Yeterlik Ölçeğinden Alınan Puanların ANOVA Sonuçları

\begin{tabular}{lccccc}
\hline Varyansın Kaynă̆ı & Kareler Toplamı & Sd & Kareler Ortalaması & F & P \\
\hline Gruplar arası & 670.659 & 3 & 223.553 & 1.127 & \\
\hline Gruplar içi & 76550.800 & 386 & 198.318 & & \\
\hline Toplam & 77221.459 & 389 & & & \\
\hline
\end{tabular}

Tablo 5 incelendiğinde, öğrencilerin duygusal öz-yeterlik ölçeğinden aldıkları puanların, anne baba tutumuna göre anlamlı bir farklılık göstermediği görülmektedir $(\mathrm{F}(3-386)=1.127, \mathrm{p}>.05)$.

Tablo 6. Algılanan Sosyo-Ekonomik Düzeye Göre, Duygusal Öz-Yeterlik Ölçeğinden Alınan Puanların ANOVA Sonuçları

\begin{tabular}{lccccc}
\hline Varyansın Kaynağı & Kareler Toplamı & Sd & Kareler Ortalaması & F & P \\
\hline Gruplar arası & 89.509 & 2 & 44.754 & .225 \\
\hline Gruplar içi & 77131.950 & 387 & 199.307 & \\
\hline Toplam & 77221.459 & 389 & & & \\
\hline
\end{tabular}

Tablo 6'da görüldüğü üzere, öğrencilerin duygusal öz-yeterlik ölçeğinden aldıkları puanlar, sosyo-ekonomik düzeylerine göre anlamlı bir farklılık göstermemektedir $(\mathrm{F}(2-387)=.225, \mathrm{p}>.05)$.

Tablo 7. Duygusal Öz-Yeterlik Ölçeğinden Alınan Puanların Sıkıntıya Dayanma Düzeyi İle İlişkisi*

\begin{tabular}{|c|c|c|}
\hline & & Dayanma Düzeyi \\
\hline \multirow{3}{*}{ Duygusal Öz-Yeterlik } & Korelasyon (r) & $.196 * *$ \\
\hline & Anlamlılık (p) & .000 \\
\hline & $\mathrm{N}$ & 384 \\
\hline
\end{tabular}

* Pearson Momentler Çarpım Korelasyon Katsayısı

$* * \mathrm{p}<0.01$

Tablo 7 incelendiğinde, öğrencilerin duygusal öz-yeterlik ölçeğinden aldıkları puanlar ile sıkıntıya dayanma düzeyi arasında $(\mathrm{r}=.196, \mathrm{p}<0.01)$ anlamlı ve pozitif yönde bir ilişki olduğu görülmektedir.

Tablo 8. Duygusal Öz-Yeterlik İle Sıkıntıya Dayanma Düzeyi Arasındaki Regresyon Bulguları

\begin{tabular}{lcccccc}
\hline Değişken & B & Standart Hata & Beta & $\mathbf{t}$ & $\mathbf{P}$ & $\mathbf{R}^{2}$ \\
\hline Sabit & 103.853 & 3.500 & & 29.676 & .000 & .196 \\
\hline $\begin{array}{l}\text { Sikıntıya } \\
\text { Dayanma }\end{array}$ & .285 & .073 & .196 & 3.909 & .000 & \\
\hline
\end{tabular}


Tablo 8'de görüldüğü üzere, öğrencilerin sıkıntıya dayanma düzeyinin duygusal öz-yeterlik üzerinde anlamlı $(\mathrm{F}(1-382)=15.28$, $\mathrm{p}<.05)$ bir etkisi bulunmaktadır. Bu modele göre sıkıntıya dayanma düzeyi duygusal öz-yeterlikteki varyansın \%3.8'ini açıklamaktadır $\left(\mathrm{R}=.196, \mathrm{R}^{2}=.038\right)$.

\section{Sonuç, Tartışma ve Öneriler}

$\mathrm{Bu}$ araştırmada, duygusal öz-yeterlik düzeyi ile cinsiyet, kardeş sayısı, algılanan anne baba tutumu, algılanan sosyoekonomik düzey ve sıkıntıya dayanma düzeyi arasındaki ilişki incelenmiştir.

Araştırmanın sonucunda, duygusal öz-yeterlik ile cinsiyet arasında anlamlı bir farklılık olmadığı bulunmuştur.

Konuyla ilişkili yazında, çalışmamızla benzer şekilde, duygusal öz-yeterliliğin, cinsiyetle ilişkisinin olmadığını söyleyen çalışmaların yanı sıra; bizim araştırmamızdan farklı olarak böyle bir ilişkinin olduğunu belirten çalışmalar da vardır.

Bizim çalışmamızla benzer şekilde Özerkan (2007); Üstüner vd., (2009); Colomeischi ve Colomeischi (2014) ve ÖzkanDeniz (2015) cinsiyetin duygusal öz-yeterlik üzerinde bir etkisinin olmadığı sonucuna ulaşmışlardır. Buna karşın, Telef ve Karaca (2011) ergenlerin duygusal öz-yeterliklerinin cinsiyete göre anlamlı düzeyde farklılıklar gösterdiğini, erkeklerin duygusal öz-yeterliklerinin kızlardan daha yüksek olduğunu saptamışlardır. Benzer şekilde, Bussey ve Bandura, (1999); Muris, (2001); Bacchini ve Maglliulo, (2003) ve Landon, Ehrenreich ve Pincus, (2007) yaptıkları çalışmalarda, erkeklerin duygusal öz-yeterliklerinin kızlardan daha yüksek olduğunu ifade etmişlerdir. Buna karşın Williemse, (2008); Ceylan (2013) tarafından yapılan çalışmalarda, kızların duygusal öz-yeterliklerinin daha yüksek olduğu bulunmuştur.

Araştırmanın bulguları, duygusal öz-yeterlik ile kardeş sayısı arasında istatistiksel olarak anlamlı bir farklılık olmadığını göstermektedir.

Konuyla ilgili yazında, bizim çalışmamızla benzer şekilde, Telef (2011) ve Ceylan (2013) tarafindan yapılan çalışmalarda, kardeş sayısının ergenlerin duygusal özyeterlikleri üzerinde etkili olmadığg saptanmıştır.

Anne baba tutumu ile duygusal öz-yeterlik arasındaki ilişkiyle ilgili bulgular incelendiğinde, duygusal öz-yeterliliğin, anne baba tutumuna göre anlamlı bir farklılık göstermediği söylenebilir. Bu bulgu, Ceylan (2013) tarafından yapılan çalışmayla paralellik göstermektedir. Söz konusu çalışmada ergenlerin algilanan anne baba tutumunun, duygusal özyeterlikleri üzerinde etkili olmadığı saptanmıştır.

Çalışmamızdan farklı olarak; Demirdüzen (2013) duygusal özyeterliliğin alt boyutlarının, anne tutumuna göre anlamlı bir farklılık gösterdiğini, anne tutumlarını aşırı hoşgörülü ve destekleyici olarak algılayan ergenlerin, düşünceyi destekleyici olarak kullanma duygusal öz-yeterlik düzeylerinin, anne tutumunu aşırı koruyucu algılayanlardan daha yüksek olduğunu ifade etmişlerdir. Buna karşın; duygusal öz-yeterliliğin alt boyutları ile baba tutumu arasında istatistiksel olarak anlamlı bir fark bulunmamıştır.

Özkan-Deniz (2015) baba tutumuna göre, duygusal özyeterliliğin alt boyutlarından düzenleme öz-yeterliliğinde istatiksel olarak anlamlı bir farklılaşma olduğunu, babasının tutumunu demokratik ve izin verici olarak algilayan ergenlerin, duyguları düzenleme öz-yeterliliklerinin, otoriter olarak algılayan ergenlerden daha yüksek olduğu bulunmuştur. Ancak algılanan anne tutumu ile duygusal özyeterlik ve alt boyutları arasında istatiksel olarak anlamlı bir farklılık olmadığı sonucuna ulaşılmıştır.

Araştırmanın başka bir bulgusuna göre, duygusal öz-yeterlik ile sosyo-ekonomik düzey arasında anlamlı bir farklılık bulunmamıştır. Araştırmamız, Telef (2011); Ceylan (2013); Demirdüzen (2013) tarafından yapılan çalışmalarla benzerlik göstermektedir. İlgili araştırmalarda, sosyo-ekonomik durumun, duygusal öz-yeterlik düzeyleri üzerinde etkili olmadığg sonucuna ulaşılmıştır.

Buna karşın, İkiz ve Sakarya-Çınkı (2016) sosyo-ekonomik düzey ile duygusal öz-yeterlik arasında istatistiksel olarak anlamlı bir farklılık olduğunu, ailesinin sosyo-ekonomik düzeyi yüksek olanların, düşük olanlara göre duygusal özyeterliliğin duygusal destekleme ve duygusal algılama alt boyut puanlarının yüksek olduğunu ifade etmişlerdir. Cinsiyet, kardeş sayısı, algılanan anne baba tutumu, algılanan sosyo-ekonomik düzey ile duygusal öz-yeterlik arasındaki ilişki konusunda farklı örneklem gruplarında yapılan çalışmalarda hem ilişki olduğuna hem de ilişki olmadığına dair sonuçlar elde edilmiştir. Bu araştırmada bütün değişkenler ile duygusal öz-yeterlik arasında ilişki olmadığı bulunmuştur. Alan yazın ile bu farklılık çalışmanın yapıldığı örneklem grubuyla ilişkili olabilir.

$\mathrm{Bu}$ araştırmada, duygusal öz-yeterlik ile sıkıntıya dayanma düzeyi arasında anlamlı ve pozitif yönde bir ilişki olduğu ve sıkıntıya dayanma düzeyinin duygusal öz-yeterlik üzerinde anlamlı bir etkisinin bulunduğu saptanmıştır. Elde edilen bu sonucun literatür ile uyumlu olduğu söylenebilir. Duygusal özyeterlik düzeyi arttıkça olumsuz duygusal durumlara dayanma gücünün de arttığı söylenebilir. Simons ve Gaher (2005) ve Huang, Szabó \& Han (2009) sıkıntıya dayanma düzeyi düşük olan bireylerin, sıkıntı ve üzüntü verici durumlarla başa çıkamadığını ve sıkıntılarını dayanılmaz olarak gördüklerini, aşırı ve kontrol edilemeyen endişe geliştirme olasılığı bulunduğunu belirtmiştir. Benzer şekilde düşük düzeyde duygusal öz-yeterliliğe sahip bireyler, olumsuz duygusal durum karşısında düşüncelerini kontrol edememekte, daha fazla umutsuzluk yaşamakta ve düşük performans sergilemektedir. Bu bireylerin hedeflerine olan inançları daha az, stres ve depresyona daha yatkındırlar (Bandura vd., 1999; Marat, 2003). Sikıntı yaratan olumsuz duygusal durumlara dayanan bireylerin kendisinin ve başkalarının duygularını algılama, anlama, destekleme ve düzenleme konularında daha yeterli olduğu söylenebilir. Bu anlamda bu bireylerin duygusal zeka, empati ve iletişim becerilerinin de daha gelişmiş olduğu söylenebilir.

Elde edilen sonuçlar ışı ğında aşağıdaki öneriler geliştirilebilir:

1. Bu çalışmada, duygusal öz-yeterliğin cinsiyet, kardeş sayısı, algilanan anne baba tutumu, algılanan sosyo-ekonomik düzey gibi demografik değişkenler ile ilişkisi incelenmiştir. Bundan sonra yapılacak çalışmalarda duygusal öz-yeterliğin farklı demografik değişkenlerle ilişkileri incelenebilir.

2. Bu araştırma, sadece eğitim fakültesinde öğrenim gören öğrenciler ile yürütülmüştür. Farklı fakültelerden öğrenciler üzerinde benzer çalışmalar yapılarak elde edilen sonuçlar karşılaştırılabilir. 
3. Sikıntıya dayanma ve duygusal öz-yeterlik kavramlarının birbiriyle ilişsili oldukları kabul edildiğinden, bireylerin bu özellikleri kazanmalarını sağlamak amacıyla ilköğretimden itibaren rehberlik uygulamalarında ya da ders programlarında çeşitli etkinliklere yer verilebilir.

4. Duygusal öz-yeterliği düşük olan diğer bir ifadeyle kendisinin ve başkalarının duygularını anlama, düzenleme, destekleme ve algılama yeterliğinde sorun yaşayan bireylere empati, duygusal zeka eğitimi, sosyal beceri eğitimi, iletişim becerileri gibi duygusal öz-yeterliği geliştirici çalışmalar yapılabilir.

\section{Kaynakça}

Akça, F. (2016). Zihinsel yetersizlikten etkilenmiş ve normal gelişim gösteren çocuğa sahip ebeveynlerin sıkıntıy tolere etme durumlart ile depresyon, anksiyete ve stres düzeyleri arasındaki ilişkinin incelenmesi. Yüksek Lisans Tezi. Karabük: Karabük Üniversitesi.

Akın, A., Akça, M. Ş., \& Gülşen, M. (2014). Sıkıntıyı tolere etme ölçeği Türkçe formu: geçerlik ve güvenirlik çalışması. Kastamonu Ĕ̆itim Dergisi, 23(2), 619-630.

Anestis, M. D., Selby, E. A., Fink, E., \& Joiner, T. E. (2007). The multifaceted role of distress tolerance in dysregulated eating behaviors. International Journal of Eating Disorders, 40(8), 718-726.

Bacchini, D., \& Magliulo, F. (2003). Self-image and perceived self-efficacy during adolescence. Journal of Youth and Adolescence, 32(5), 337-350.

Bandura, A. (1982). Self-efficacy mechanism in human agency. American Psychologist, 37, 122-147.

Bandura, A. (1994). Self-efficacy. In V. S. Ramachaudran (Ed.), Encyclopedia of human behavior (Vol. 4, pp. 71-81). New York: Academic Press.

Bandura, A. (1997). Self-efficacy: The exercise of control. New York: Freeman.

Bandura, A., Pastorelli, C., Barbaranelli, C., \& Caprara, G. V. (1999). Self-efficacy path ways to childhood depression. Journal of Personality and Social Psychology, 76, 258269.

Brockman, C. J. (2009). Urgency and distress tolerance predicting alcohol use, alcohol-related problems, and alcohol use as a coping mechanism. Master's thesis, University of Central Missouri.

Brown, R. A., Lejuez, C. W., Kahler, C. W., Strong, D. R., \& Zvolensky, M. J. (2005). Distress tolerance and early smoking lapse. Clinical Psychology Review, 25, 713-733.

Bussey, K., \& Bandura, A. (1999). Social cognitive theory of gender development and differentiation. Psychological Review, 106, 676-713.

Caprara, G. V., Giunta, L. D., Eisenberg, N., Gerbino, M., Pastorelli, C., \& Tramontano, C. (2008). Assessing regulatory emotional self-efficacy in three countries. Psychological Assessment, 20(2), 227-237.

Ceylan, İ. (2013). Ergenlerin benlik saygiss ve duygusal özyeterlik düzeylerinin incelenmesi. Yüksek Lisans Tezi. İzmir: Dokuz Eylül Üniversitesi.
Colomeischi, A. A., \& Colomeischi, T. (2014). Teachers'attitudes towards work in relation with emotional intelligence and self-efficacy. Procedia-Social and Behavioral Sciences, 159, 615-619.

Demirdüzen, H. (2013). Ergenlerin algllanan sosyal destek düzeyleri ile duygusal özyeterlik düzeylerinin incelenmesi. Yüksek Lisans Tezi. İzmir: Dokuz Eylül Üniversitesi.

Huang, K., Szabo, M., \& Han, J. (2009). The relationship of low distress tolerance to excessive worrying and cognitive avoidance. Behavior Change, 26(4), 223-234.

İkiz, F. E., \& Sakarya-Çınkı, Ö. (2016). Ergenlerin ruhsal belirtileri ile duygusal öz-yeterlik düzeylerinin incelenmesi. Turkish Studies, 11(14), 333-348.

Karasar, N. (1995). Bilimsel araştırma yöntemi: kavramlar, ilkeler, teknikler. Ankara: Araştırma Eğitim Danışmanlık Ltd.

Keskin, G. Ü., \& Orgun, F. (2006). Öğrencilerin öz etkililikyeterlilik düzeyleri ile başa çıkma stratejilerinin incelenmesi. Anadolu Psikiyatri Dergisi, 7, 92-99.

Kraemer, K. M., McLeish, A. C., Jeffries, E. R., Avallone, K. M., \& Luberto, C. M. (2013). Distress tolerance and perceived barriers to smoking cessation. Substance Abuse, 34, 277-282.

Kirk, B. A., Schutte, N. S., \& Hine, D. W. (2008). Development and preliminary validation of an emotional self-efficacy scale. Personality and Individual Differences, 45(5), 432-436.

Kirk, B. A., Schutte, N. S., \& Hine, D. W. (2011). The effect of an expressive-writing intervention for employees on emotional self-efficacy, emotional intelligence, affect, and workplace incivility. Journal of Applied Social Psychology, 41(1), 179-195.

Landon, T. M., Ehrenreich, J. T., \& Pincus, D. B. (2007). Selfefficacy: A comparison between clinically anxious and non-referred youth. Child Psychiatry \& Human Development, 38, 31-45.

Leyro, T. M., Zvolensky, M. J., \& Bernstein, A. (2010). Distress tolerance and psychopathological symptoms and disorders: A review of the empirical literature among adults. Psychological Bulletin, 136, 576-600.

Marat, D. (2003). Assessing self-efficacy and agency of secondary school students in a multi-cultural context: Implications for academic achievement. Proceedings of the New Zealand and Australian Association for Research in Education Conference, Auckland, http://www.aare.edu.au/03pap/mar03057.pdf.(12 Aralik 2012).

Mayer, J. D., \& Salovey, P. (1997). What is emotional intelligence? P.Salovey ve D. J. Sluyter (Eds.), Emotional development and emotional intelligence (syf. 396-420). New York: Basic Books.

Mayer, J. D., Salovey, P., \& Caruso, D. R. (2004). Emotional intelligence: theory, findings, and implications. Psychological Inquiry, 15(3), 197-215.

Mengi, S. (2011). Ortaöğretim 10. ve 11. sinıf öğrencilerinin sosyal destek ve özyeterlik düzeylerinin okula bağlllıklarl 
ile ilişkisi. Yüksek Lisans Tezi. Sakarya: Sakarya Üniversitesi.

Muris, P., Mayer, B., Van Lint, C., \& Hofman, S. (2008). Attentional control and psychopathological symptoms in children. Personality and Individual Differences, 44(7), 1495-1505.

Muris, P. (2001). A brief questionnaire for measuring selfefficacy in youths. Journal of Psychopathology and Behavioral Assessment, 23, 145-149.

Muris, P. (2002). Relationships between self-efficacy and symptoms of anxiety disorders and depression in anormal adolescent sample. Personality and Individual Differences, $32,337-348$.

Nelson, G. (1990). Women's life strains, social support, coping, and positive and negative affects: cross-sectional and longitudinal tests of the two-factor theory of emotional well-being. Journal of Community Psychology, 18, 239263.

Özerkan, E. (2007). Öğretmenlerin öz-yeterlik algıları ile ögrencilerin sosyal bilgiler benlik kavramları arasındaki ilişki. Yüksek Lisans Tezi, Edirne: Trakya Üniversitesi.

Özkan-Deniz, B. (2015). Ergenlerde duygusal öz-yeterlik ve sürekli kaygı ilişkisinin incelenmesi. Yüksek Lisans Tezi. İzmir: Dokuz Eylül Üniversitesi.

Petrides, K. V., \& Furnham, A. (2001). Trait emotional intelligence: psychometric investigation with reference to established trait taxonomies. European Journal of Personality, 15(6), 425-448.

Petrides, K. V., \& Furnham, A. (2003). Trait emotional intelligence: behavioral validation in two studies of emotion recognition and reactivity to mood induction. European Journal of Personality, 17(1), 39-57.

Saarni, C. (1999). The development of emotional competence. New York: Guilford.

Sahranç, Ü. (2007). Stres kontrolü, genel öz-yeterlik, durumluluk kaygl ve yaşam doyumu ile ilişkili bir akış modeli. Doktora Tezi. Ankara: Gazi Üniversitesi.

Sakarya, Ö. (2015). Ergenlerin ruhsal belirtileri ile duygusal öz-yeterlik düzeylerinin incelenmesi. Yüksek Lisans Tezi. İzmir: Dokuz Eylül Üniversitesi.

Sargın A. E., Özdel, K., Utku, Ç., Kuru, E., Yalçınkaya Alkar, Ö., \& Türkçapar, M. H. (2012). Sıkıntıya dayanma ölçeği: geçerlik ve güvenilirlik çalışması. Bilişsel Davranış̧̧ı Psikoterapi ve Araştırmalar Dergisi, 1, 152-161.

Simons, J. S., \& Gaher, R. M. (2005). The distress tolerance scale: development and validation of a self-report measure. Motivation and Emotion, 29(2), 83-102.

Tahmassian, K., \& Moghadam, N. J. (2011). Relationship between self-efficacy and symptoms of anxiety, depression, worry and social avoidance in a normal sample of students. Iranian Journal of Psychiatry and Behavioral Sciences, 5(2), 91-98.

Telef, B. B. (2011). Özyeterlikleri farklı ergenlerin psikolojik sempomlarının incelenmesi. Doktora Tezi. İzmir: Dokuz Eylül Üniversitesi.
Telef, B. B., \& Karaca, R. (2011). Ergenlerin öz-yeterliklerinin ve psikolojik semptomlarının incelenmesi. Mustafa Kemal Üniversitesi Sosyal Bilimler Enstitüsü Dergisi, 16, 499518.

Totan, T., İkiz, E., \& Karaca, R. (2010). Duygusal öz-yeterlik ölçeğinin Türkçeye uyarlanarak tek ve dört faktörlü yapısının psikometrik özelliklerinin incelenmesi. Dokuz Eylül Üniversitesi Buca Eğitim Fakültesi Dergisi, 28, 7195.

Üstüner, M., Demirtaş, H., Cömert, M., \& Özer, N. (2009). Ortaöğretim öğretmenlerinin öz-yeterlik algıları. Mehmet Akif Ersoy Üniversitesi Eğitim Fakültesi Dergisi, 9(17), 116.

Willemse, M. (2008). Exporing the relationship betwen selfefficacy and aggression in a group of adolescents in the peri-urban town of worcester. Master of Art Thesis. University of Stellenbosch. 